\title{
ALTITUDE AND GEOGRAPHIC COORDINATES TO ESTIMATE MONTHLY RAINFALL IN THE STATE OF MATO GROSSO DO SUL
}

\author{
ALTITUDE E COORDENADAS GEOGRÁFICAS NA ESTIMATIVA DA CHUVA MENSAL \\ NO ESTADO DE MATO GROSSO DO SUL
}

\section{Paulo Eduardo TEODORO'; ; Elias Rodrigues da CUNHA²; Caio Cézar Guedes CORRÊA ${ }^{\mathbf{1}}$; Larissa Pereira RIBEIRO'; ; Francisco Eduardo TORRES'; José Francisco de OLIVEIRA-JUNIOR; Givanildo GOIS ${ }^{3}$; Victor Matheus BACANI ${ }^{2}$}

1. Departamento de Fitotecnia, Universidade Estadual de Mato Grosso do Sul - UEMS, Aquidauana, MS, Brasil. eduteodoro@hotmail.com; 2. Departamento de Geoprocessamento, Universidade Federal de Mato Grosso do Sul - UFMS, Aquidauana, MS, Brasil; 3. Departamento de Ciências Ambientais, Universidade Federal do Rio de Janeiro - UFRRJ, Rio de Janeiro, RJ, Brasil.

\begin{abstract}
Adjustment of multiple linear regression equations has allowed estimating the value of a certain climatological variable according to geographical coordinates with acceptable degree of accuracy. The aim of this study was to verify if the average monthly rainfall could be estimated according to the altitude, latitude and longitude in Mato Grosso do Sul State (MS). Rainfall data of 32 stations of MS were collected from 1954 to 2013. It were formed 384 time series (12 months $\times 32$ sites), with different numbers of years of observations in each series. On each of the 384 monthly rainfall time series it was calculated the average (a), at least 30 years of observation, forming 12 matrices $32 \times 4$ (32 sites x 4 variables: altitude, latitude, longitude and monthly rainfall). It was estimated for each matrix the Pearson's linear correlation coefficient among the variables, performing the multicollinearity diagnosis for each matrix. Correlations were unfolded by path analysis in direct and indirect effects and in each month it was used the multiple linear regression model. The altitude and latitude have greater effect on the spatial distribution of rainfall in MS. The multiple linear regression equations generated in this study will subsidize researches of crop zoning, indication for sowing times, irrigation, determination of yield potential, climate risks zoning and credit and agricultural insurance.
\end{abstract}

KEYWORDS: Correlation. Multiple linear regression. Path analysis.

\section{INTRODUCTION}

Mato Grosso do Sul State (MS) covers an area of approximately $350,000 \mathrm{~km}^{2}$, of which $13,000 \mathrm{~km}^{2}$ are exploited by agriculture, especially for soybean, corn, cotton, sugarcane sugar and irrigated rice $(\mathrm{CONAB}$, 2014). Among the main factors that influence crop production is rain, because its spatial distribution and temporal variability interfere with agricultural planning, namely, the better time of tillage, harvest, sowing, defensive application and supplementary irrigation (CORRÊA et al., 2014; LYRA et al., 2014; TEODORO et al., 2015a,b; TORRES et al., 2016).

Adjustment of multiple linear regression equations has allowed estimating the value of a certain climatological variable according to the longitude, latitude and altitude; this methodology is widely used in the literature and has presented an acceptable degree of accuracy (MEDEIROS et al., 2005). The estimate of the minimum, medium and maximum monthly and annual air temperatures from the geographic coordinates has been the subject of several studies in different states and regions of Brazil (FERREIRA et al., 1971; COELHO et al., 1973; FERREIRA et al., 1974; FEITOZA et al., 1980a; FEITOZA et al., 1980b; CAMARGO, GHIZZI, 1991; PEDRO JÚNIOR et al., 1991; CAVALCANTI, SILVA, 1994; LUIZ, SILVA, 1995; LIMA, RIBEIRO, 1998; SEDIYAMA, MELO JÚNIOR, 1998;
SEDIYAMA et al., 2002; MARIN et al., 2003; MEDEIROS et al., 2005; CARGNELUTTI FILHO et al., 2006; CARGNELUTTI FILHO et al., 2008).

However, did not find any work in the literature that investigated the hypothesis of obtaining the average monthly rainfall by altitude and geographical variables in Midwest region, especially in MS, deficient climatological research. The aim of this study was to verify if the average monthly rainfall could be estimated according to the altitude, latitude and longitude in sites of Mato Grosso do Sul State.

\section{MATERIAL AND METHODS}

\section{Study area}

Mato Grosso do Sul State is located in the Midwest of Brasil. Has a total area of $357,145.32 \mathrm{~km}^{2}$, composed of 79 municipalities. The state has several features edaphoclimatic distributed among three biomes with peculiar climatic attributes: Savanna, Atlantic Forest and Pantanal. Altitudes ranged from 24 to 1000 $\mathrm{m}$, in the center of the South American continent.

In the state there are three major topographical units: i) Pantanal, in the west portion, with a singular drainage network, spread over an immense plain of modest altitudes between 80 to $200 \mathrm{~m}$; ii) in the center, shows the Divisor Plateau or Serra de Maracajú, elongated in the NE-SW direction, separating the waters 
of the Paraguay and Paraná river basins, with altitudes ranging from $300 \mathrm{~m}$ (Serra de Bodoquena) to over 650 $\mathrm{m}$ (Plateau of Amambaí); and iii) in the eastern portion, is located the Alto Paraná shaft, drained by major rivers of arenitic-basalt plateau, with altitudes ranging between 200 and $250 \mathrm{~m}$ along the trough (ZAVATTINI, 2009).

\section{Data collection}

Rainfall data of 32 stations (sites) of Mato Grosso do Sul (MS) were obtained of the National
Water Agency Database (ANA, 2014), collected from 1954 to 2013 (Table 1). At each site and year, the rainfall daily data were added up to obtain the monthly rainfall (mm monthly ${ }^{-1}$ ), of each month of the year. Thus, were formed 384 time series (12 months $\times 32$ sites), with different numbers of years of observations in each series, defined according to the availability of meteorological data.

Table 1. Altitude (m), latitude and longitude $\left(^{\circ}\right)$ and observation period of monthly rainfall of 32 municipalities in Mato Grosso do Sul, Brazil.

\begin{tabular}{|c|c|c|c|c|}
\hline Site & Altitude (m) & Latitude $\left(\mathrm{S},{ }^{\circ}\right)$ & Longitude $\left(\mathrm{W},{ }^{\circ}\right)$ & Period \\
\hline Água Clara & 376 & $20^{\circ} 6^{\prime} 7^{\prime \prime}$ & $52^{\circ} 55^{\prime} 33^{\prime \prime}$ & $1975-2013$ \\
\hline Amambai & 395 & $22^{\circ} 55^{\prime} 59^{\prime \prime}$ & $55^{\circ} 13^{\prime} 0^{\prime}$ & $1973-2013$ \\
\hline Anastácio & 106 & $19^{\circ} 34^{\prime} 0^{\prime \prime}$ & $56^{\circ} 12^{\prime} 0^{\prime \prime}$ & $1960-2000$ \\
\hline Anaurilândia & 284 & $22^{\circ} 11^{\prime} 11^{\prime \prime}$ & $52^{\circ} 42^{\prime} 48^{\prime \prime}$ & $1975-2013$ \\
\hline Aparecida do Taboado & 375 & $20^{\circ} 1^{\prime} 6^{\prime \prime}$ & $51^{\circ} 6^{\prime} 13^{\prime \prime}$ & $1983-2013$ \\
\hline Aquidauana & 155 & $20^{\circ} 27^{\prime} 24^{\prime \prime}$ & $55^{\circ} 40^{\prime} 17^{\prime \prime}$ & $1960-2000$ \\
\hline Bataguassu & 293 & $21^{\circ} 43^{\prime} 33^{\prime \prime}$ & $52^{\circ} 20^{\prime} 3^{\prime \prime}$ & $1975-2013$ \\
\hline Bodoquena & 133 & $19^{\circ} 52^{\prime} 15^{\prime \prime}$ & $56^{\circ} 59^{\prime} 1^{\prime \prime}$ & $1954-2013$ \\
\hline Caarapó & 454 & $22^{\circ} 37^{\prime} 28^{\prime}$, & $54^{\circ} 49^{\prime} 29^{\prime \prime}$ & $1973-2013$ \\
\hline Camapuã & 404 & $19^{\circ} 29^{\prime} 48^{\prime \prime}$ & $53^{\circ} 59^{\prime} 48^{\prime \prime}$ & $1973-2013$ \\
\hline Campo Grande & 559 & $20^{\circ} 28^{\prime} 0^{\prime}$ & $54^{\circ} 40^{\prime} 0^{\prime}$, & $1975-2013$ \\
\hline Chapadão do Sul & 570 & $18^{\circ} 59^{\prime} 52^{\prime \prime}$ & $52^{\circ} 35^{\prime} 17^{\prime \prime}$ & $1983-2013$ \\
\hline Corumbá & 101 & $17^{\circ} 37^{\prime} 24^{\prime}$, & $56^{\circ} 57^{\prime} 54^{\prime \prime}$ & $1983-2013$ \\
\hline Costa Rica & 635 & $18^{\circ} 32^{\prime} 50^{\prime \prime}$ & $53^{\circ} 8^{\prime} 7^{\prime}$, & $1983-2013$ \\
\hline Coxim & 250 & $18^{\circ} 38^{\prime} 57^{\prime}$, & $54^{\circ} 21^{\prime} 26^{\prime \prime}$ & $1973-2013$ \\
\hline Dourados & 293 & $22^{\circ} 23^{\prime} 53^{\prime}$, & $54^{\circ} 47^{\prime} 30^{\prime \prime}$ & $1973-2013$ \\
\hline Glória de Dourados & 422 & $22^{\circ} 24^{\prime} 21^{\prime \prime}$ & $54^{\circ} 14^{\prime} 7^{\prime}$, & $1973-2013$ \\
\hline Iguatemi & 333 & $23^{\circ} 40^{\prime} 55^{\prime}$, & $54^{\circ} 33^{\prime} 42^{\prime}$, & $1975-2013$ \\
\hline Inocência & 502 & $19^{\circ} 44^{\prime} 11^{\prime \prime}$, & $51^{\circ} 56^{\prime} 1^{\prime \prime}$ & $1983-2013$ \\
\hline Maracaju & 356 & $21^{\circ} 37^{\prime} 7^{\prime}$ & $55^{\circ} 8^{\prime} 13^{\prime \prime}$ & 1973-2013 \\
\hline Miranda & 140 & $20^{\circ} 6^{\prime} 7^{\prime \prime}$ & $56^{\circ} 47^{\prime} 43^{\prime \prime}$ & $1960-2000$ \\
\hline Navirai & 366 & $23^{\circ} 3^{\prime} 28^{\prime \prime}$ & $54^{\circ} 11^{\prime} 38^{\prime \prime}$ & $1975-2013$ \\
\hline Nova Andradina & 271 & $21^{\circ} 36^{\prime} 55^{\prime \prime}$ & $53^{\circ} 3^{\prime} 8^{\prime}$ & $1975-2013$ \\
\hline Paranaíba & 458 & $19^{\circ} 23^{\prime} 27^{\prime \prime}$ & $51^{\circ} 36^{\prime} 32^{\prime \prime}$ & $1983-2013$ \\
\hline Ponta Porã & 650 & $22^{\circ} 32^{\prime} 0^{\prime}$ & $55^{\circ} 43^{\prime} 0^{\prime \prime}$ & 1973-2013 \\
\hline Porto Murtinho & 83 & $21^{\circ} 42^{\prime} 5^{\prime}$ & $57^{\circ} 53^{\prime} 30^{\prime \prime}$ & $1983-2013$ \\
\hline Ribas do Rio Pardo & 373 & $20^{\circ} 26^{\prime} 41^{\prime \prime}$ & $53^{\circ} 45^{\prime} 29^{\prime \prime}$ & $1975-2013$ \\
\hline Rio Brilhante & 287 & $21^{\circ} 38^{\prime} 50^{\prime \prime}$ & $54^{\circ} 25^{\prime} 31^{\prime \prime}$ & $1973-2013$ \\
\hline Rio Negro & 233 & $19^{\circ} 26^{\prime} 23^{\prime \prime}$ & $54^{\circ} 59^{\prime} 0^{\prime \prime}$ & $1975-2013$ \\
\hline Santa Rita do Pardo & 393 & $21^{\circ} 17^{\prime} 43^{\prime}$, & $52^{\circ} 48^{\prime} 38^{\prime \prime}$ & $1975-2013$ \\
\hline Selviria & 348 & $20^{\circ} 21^{\prime} 49^{\prime \prime}$ & $51^{\circ} 25^{\prime} 26^{\prime \prime}$ & $1983-2013$ \\
\hline Três Lagoas & 313 & $20^{\circ} 47^{\prime} 41^{\prime \prime}$ & $51^{\circ} 42^{\prime} 46^{\prime \prime}$ & $1975-2013$ \\
\hline
\end{tabular}

\section{Statistical analysis}

On each of the 384 monthly rainfall time series it was calculated the average (a), at least 30 years of observation, forming 12 matrices $32 \times 4$, being 32 the number of sites and 4 the number of variables (altitude, latitude, longitude and monthly rainfall). Initially, we estimated for each matrix the Pearson's linear correlation coefficient (r) among the variables. The multicollinearity diagnosis was performed for each matrix to keep control about which variables (very correlated with others) could be excluded from the study in order to avoid estimates of biased direct and indirect effects in path analysis.

Subsequently, the correlations were unfolded by path analysis in direct and indirect effects, considering the following model: $Y=p_{1} X_{1}+p_{2} X_{2}+\ldots+p_{n} X_{n}+p_{\varepsilon} u$, 
wherein $\mathrm{Y}$ is the principal dependent variable (monthly rainfall); $\mathrm{X}_{1}, \mathrm{X}_{2}, \ldots, \mathrm{X}_{\mathrm{n}}$ : are the independent explanatory variables (altitude, latitude, longitude); $\mathrm{p}_{1}, \mathrm{p}_{2}, \ldots, \mathrm{p}_{\mathrm{n}}$ : are the path analysis coefficients. The coefficient of determination was calculated by the expression $\mathrm{R}^{2}=\mathrm{p}_{1 \mathrm{y}}{ }^{2}$ $+\mathrm{p}_{2 \mathrm{y}}{ }^{2}+\ldots 2 \mathrm{p}_{2 \mathrm{y}} \mathrm{p}_{2 \mathrm{n}} \mathrm{r}_{2 \mathrm{n}}$.

In each month, we used the multiple linear regression model with $\mathrm{k}$ independent variables: $Y_{j}=\beta_{0}+\sum_{i=1}^{k} \beta_{i} x_{i}+\varepsilon_{i}$, wherein $Y_{j}$ is the observed value of the average monthly rainfall; $\beta_{0}$ is the linear coefficient; $\beta_{\mathrm{i}}$ is the regression coefficient of the independent variables $\mathrm{X}_{\mathrm{i}} ; \mathrm{X}_{\mathrm{ij}}$ are the independent variable $X_{i}$ in the observation $j$; and $\varepsilon$ is the error associated to variable $\mathrm{Y}$ in the observation $\mathrm{j}$. In this model, the variable $\mathrm{Y}$ is the linear function of the independent variables; the values of the independent variables are fixed; and errors has zero average, are homocedastic, independent and with normal distribution (HOFFMANN; VIEIRA, 1998; SOUZA, 1998).

The parameters of multiple linear regression equations model were estimated by step by step with test for variable output (stepwise backward), being the average monthly rainfall the dependent variable and the other (altitude, latitude and longitude) the independents, as performed by Cargnelutti Filho et al. (2006, 2008). Statistical analyzes were carried out with the applications GENES (CRUZ, 2013) and Microsoft Office Excel ${ }^{\circledR}$.

\section{RESULTS AND DISCUSSION}

There was similar score and signal of $\mathrm{r}$ coefficient among the average monthly rainfall and altitude $(0.29<\mathrm{r}<0.57)$ and longitude $(-0.58<\mathrm{r}<-0.41)$ (Table 2). Cargnelutti Filho et al. (2006) and Cargnelutti Filho et al. (2008) when estimating the maximum and minimum decendial temperatures in Rio Grande do Sul State, respectively, through the altitude and geographic coordinates verified $r$ in similar magnitudes to those observed in this study. In principle, these results indicate that rainfall in Mato Grosso do Sul State is directly related to the geographic distribution of its municipalities.

Table 2. Estimate of Pearson's correlation coefficient (r) among average monthly rainfall ( $\left.\mathrm{mm} \mathrm{month}{ }^{-1}\right)$ with the altitude $(\mathrm{m})$, latitude and longitude $\left({ }^{\circ}\right)$ in Mato Grosso do Sul, Brazil.

\begin{tabular}{lccc}
\hline Month & Altitude $(\mathrm{m})$ & Latitude $\left(\mathrm{S},{ }^{\circ}\right)$ & Longitude $\left(\mathrm{W},{ }^{\circ}\right)$ \\
\hline January & $0.42^{*}$ & $-0.62^{* *}$ & $-0.56^{* *}$ \\
February & $0.56^{* *}$ & $-0.40^{*}$ & $-0.58^{* *}$ \\
March & $0.57^{* *}$ & $-0.52^{* *}$ & $-0.51^{* *}$ \\
April & $0.44^{*}$ & $0.37^{*}$ & $0.13^{\text {ns }}$ \\
May & $0.20^{\text {ns }}$ & $0.78^{* *}$ & $0.21^{\text {ns }}$ \\
June & $0.05^{\text {ns }}$ & $0.79^{* *}$ & $0.27^{\text {ns }}$ \\
July & $0.05^{\text {ns }}$ & $0.84^{* *}$ & $0.20^{\text {ns }}$ \\
August & $0.21^{\text {ns }}$ & $0.78^{* *}$ & $0.10^{\text {ns }}$ \\
September & $0.29^{*}$ & $0.81^{* *}$ & $-0.02^{\text {ns }}$ \\
October & $0.45^{*}$ & $0.54^{* *}$ & $0.06^{\text {ns }}$ \\
November & $0.53^{* *}$ & $0.05^{\text {ns }}$ & $0.10^{\text {ns }}$ \\
December & $0.47^{* *}$ & $-0.55^{* *}$ & $-0.41^{*}$
\end{tabular}

ns, $*$ and $* *$ not significant, sigificant at 5 and $1 \%$ probability, respectively, by t-test, with 29 degrees of freedom.

The monthly rainfall positively correlated with altitude in the months from September to April (dry season). The monthly rainfall correlated positively with latitude in the months from April to October and negatively in the months from December to March. The monthly rainfall was negatively correlated with the longitude in the months from December to January (wet season). The topographic aligning, arranged in the longitudinal direction (NE-SW), shows morphological features well defined: the plain and the plateau. This arrangement exerts strong influence in the rainfall behavior in Mato Grosso do Sul State (NIMER, 1989; CORRÊA et al., 2014; TEODORO et al., 2015a,b). Given these results, we can infer that a multiple linear regression model is adequate to estimate the average monthly rainfall according to altitude, latitude and longitude.

Estimative $r$ is a measure of association that assesses the linear relationship degree among the variables. Only this parameter is not possible to conclude what effect direct and/or indirect of the altitude, latitude and longitude on the average monthly rainfall. Thus, the path analysis is appropriate for these inferences, since investigates these relationships and provides scores, called path coefficients, which measure the influence of a variable on the other, independently from the others, allowing unfold the simple correlation coefficients in 
effect direct and indirect (VENCOVSKY; BARRIGA, 1992; TEODORO et al., 2014).

The multicollinearity diagnosis among the variables showed weak collinearity in 12 matrices of correlation coefficients, with condition number ranging between 12 and 18, which allows the performance of analysis without discarding variables for its realization. The unfolding of the total correlation of each variable (altitude, latitude and longitude) on the variable average monthly rainfall in direct and indirect effects is showed in Table 3.

Table 3. Estimate of Pearson's correlation coefficients and estimate of the direct and indirect effects of the variables altitude (ALT), latitude (LAT) and longitude (LON) on the average monthly rainfall in Mato Grosso do Sul, Brazil.

\begin{tabular}{|c|c|c|c|c|c|c|c|c|c|}
\hline Effect & ALT & LAT & LON & ALT & LAT & LON & ALT & LAT & LON \\
\hline & \multicolumn{3}{|c|}{ January } & \multicolumn{3}{|c|}{ February } & \multicolumn{3}{|c|}{ March } \\
\hline Direct on RAINF & 0.27 & 0.62 & -0.39 & 0.42 & -0.42 & -0.35 & 0,50 & -0.55 & -0.23 \\
\hline Indirect by ALT & --- & 0.02 & -0.14 & --- & 0.04 & -0.21 & --- & 0.04 & -0.25 \\
\hline Indirect by LAT & -0.05 & --- & -0.03 & -0.04 & --- & -0.02 & $-0,05$ & --- & -0.03 \\
\hline Indirect by LON & 0.20 & -0.02 & --- & 0.18 & -0.02 & --- & 0,12 & -0.01 & --- \\
\hline \multirow[t]{2}{*}{ Total $(\mathrm{r})$} & $0.42 *$ & $0.62 * *$ & $-0.56^{* *}$ & $0.56 * *$ & $0.40^{*}$ & $-0.58 * *$ & $0,57 * *$ & $-0.52 * *$ & $-0.51 * *$ \\
\hline & \multicolumn{3}{|c|}{ April } & \multicolumn{3}{|c|}{ May } & \multicolumn{3}{|c|}{ June } \\
\hline Direct on RAINF & 0.64 & 0.30 & 0.44 & 0.31 & 0.74 & 0.34 & 0,14 & 0.76 & 0.30 \\
\hline Indirect by ALT & --- & 0.05 & -0.32 & --- & 0.03 & -0.16 & --- & 0.02 & -0.07 \\
\hline Indirect by LAT & 0.03 & --- & 0.01 & 0.06 & --- & 0.03 & 0,07 & --- & 0.04 \\
\hline Indirect by LON & -0.23 & 0.02 & --- & -0.17 & 0.01 & --- & $-0,16$ & 0.02 & --- \\
\hline \multirow[t]{2}{*}{ Total (r) } & $0.44^{*}$ & $0.37 *$ & $0.13^{\mathrm{ns}}$ & $0.20^{\mathrm{ns}}$ & $0.78 * *$ & $0.21^{\mathrm{ns}}$ & $0,05^{\mathrm{ns}}$ & $0.79 * *$ & $0.27^{\mathrm{ns}}$ \\
\hline & \multicolumn{3}{|c|}{ July } & \multicolumn{3}{|c|}{ August } & \multicolumn{3}{|c|}{ September } \\
\hline Direct on RAINF & 0.08 & 0.82 & 0.20 & 0.24 & 0.75 & 0.19 & 0,26 & 0.78 & 0.08 \\
\hline Indirect by ALT & --- & 0.01 & -0.04 & --- & 0.02 & -0.12 & --- & 0.02 & -0.13 \\
\hline Indirect by LAT & 0.07 & --- & 0.04 & 0.06 & -- & 0.03 & 0,07 & --- & 0.03 \\
\hline Indirect by LON & -0.10 & 0.01 & --- & -0.09 & 0.01 & --- & $-0,03$ & 0.01 & --- \\
\hline \multirow[t]{2}{*}{ Total (r) } & $0.05^{\mathrm{ns}}$ & $0.84 * *$ & $0.20^{\mathrm{ns}}$ & $0.21^{\mathrm{ns}}$ & $0.78 * *$ & $0.10^{\mathrm{ns}}$ & $0,29^{\mathrm{ns}}$ & $0.81 * *$ & $-0.02^{\mathrm{ns}}$ \\
\hline & \multicolumn{3}{|c|}{ October } & \multicolumn{3}{|c|}{ November } & \multicolumn{3}{|c|}{ December } \\
\hline Direct on RAINF & 0.58 & 0.48 & 0.34 & 0.79 & -0.04 & 0.50 & 0,44 & -0.58 & -0.16 \\
\hline Indirect by ALT & --- & 0.05 & -0.29 & --- & 0.07 & -0.40 & --- & 0.04 & -0.22 \\
\hline Indirect by LAT & 0.04 & --- & 0.01 & 0.00 & --- & 0.00 & $-0,05$ & --- & -0.03 \\
\hline Indirect by LON & -0.17 & 0.1 & --- & -0.26 & 0.02 & --- & 0,08 & -0.01 & --- \\
\hline Total (r) & $0.45^{*}$ & $0.54 * *$ & $0.06^{\mathrm{ns}}$ & $0.53 * *$ & $0.05^{\mathrm{ns}}$ & $0.10^{\mathrm{ns}}$ & $0,47 * *$ & $-0.55^{* *}$ & $-0.41 *$ \\
\hline
\end{tabular}

ns, $*$ and $* *$ not significant, sigificant at 5 and $1 \%$ probability, respectively, by t-test, with 29 degrees of freedom.

In the 12 months of the year, the causal variable altitude showed direct effect on average monthly rainfall, which allows us to infer that largest average monthly rainfall will proceed in the highest places of Mato Grosso do Sul. This behavior demonstrates that despite tropical features present in the State, altitude is among the physiographic factors, followed by the latitude, which most influences the monthly rainfall behavior in dry, transition and rainy periods, resembling to results obtained by researches carried out in other Brazilian states (BAÚ et al. 2006; ANDRÉ et al. 2008; ÁVILA et al. 2009; TEODORO et al., 2015b).

It was observed in Table 4 a high coefficient of determination $\left(\mathrm{R}^{2}\right)$ for multiple linear regression equations for Mato Grosso do Sul, independent of the month. Cargnelutti Filho et al. (2006) and Cargnelutti Filho et al. (2008), when estimating the maximum and minimum decendial temperatures, respectively, through the altitude and geographic coordinates, verified $\mathrm{R}^{2}$ in lower magnitudes to those observed in this study. This indicates good credibility of the equations generated to estimate monthly rainfall of Mato Grosso do Sul municipalities through geographic coordinates. 
Table 4. Estimate of the parameters $\left(\beta_{0}, \beta_{1}, \beta_{2}\right.$ and $\left.\beta_{3}\right)$ of the multiple linear regression and coefficient of determination $\left(\mathrm{R}^{2}\right)$, of average monthly rainfall according to altitude $(\mathrm{m})$, latitude $\left(^{\circ}\right)$ and longitude $\left({ }^{\circ}\right)$, in Mato Grosso do Sul, Brazil.

\begin{tabular}{lccccc}
\hline Month & Constant $\left(\beta_{0}\right)$ & Altitude $\left(\beta_{1}\right)$ & Latitude $\left(\beta_{2}\right)$ & Longitude $\left(\beta_{3}\right)$ & $\mathrm{R}^{2}$ \\
\hline January & 1056.92 & -0.08 & -18.06 & -9.15 & 0,85 \\
February & 659.11 & 0.09 & -9.03 & -6.02 & 0,78 \\
March & 589.88 & 0.10 & -11.83 & -4.16 & 0,83 \\
April & -315.24 & 4.69 & 5.25 & 0.09 & 0,65 \\
May & -468.63 & 0.05 & 13.01 & 4.89 & 0,85 \\
June & -468.31 & 0.03 & 13.10 & 4.40 & 0,84 \\
July & -214.77 & 0.01 & 7.66 & 1.53 & 0,86 \\
August & -219.44 & 0.02 & 7.54 & 1.65 & 0,81 \\
September & -231.13 & 0.04 & 12.08 & 0.91 & 0,85 \\
October & -378.64 & 0.11 & 9.08 & 5.23 & 0,73 \\
November & -234.06 & 0.12 & -0.56 & 6.62 & 0,69 \\
December & 530.04 & 0.08 & -11.04 & -2.54 & 0,77 \\
\hline
\end{tabular}

\section{CONCLUSION}

The altitude and latitude have greater effect on the spatial distribution of rainfall in Mato Grosso do Sul State. The multiple linear regression equations generated in this study will subsidize researches of crop zoning, indication for sowing times, irrigation, determination of yield potential, climate risks zoning and credit and agricultural insurance.

RESUMO: O ajuste de equações de regressão linear múltipla tem possibilitado que se estime o valor de uma determinada variável climatológica em função das coordenadas geográficas com grau aceitável de acurácia. O objetivo do trabalho foi verificar se a chuva mensal média pode ser estimada em função da altitude, latitude e longitude no Estado do Mato Grosso do Sul (MS). Os dados pluviométricos de 32 estações do MS foram coletados do período de 1954 a 2013. Formaram-se 384 séries temporais (12 meses $\times 32$ locais), com número diferenciado de anos de observações em cada série. Em cada série temporal de chuva mensal calculou-se a média, formando-se 12 matrizes de 32 × 4 (32 locais e 4 variáveis: altitude, latitude, longitude e chuva mensal). Estimou-se para cada matriz o coeficiente de correlação linear de Pearson entre as variáveis, realizando-se o diagnóstico multicolinearidade para cada matriz. As correlações foram desdobradas, por meio da análise de trilha, em efeitos diretos e indiretos e em cada mês foi usado o modelo de regressão linear múltipla. A altitude e latitude exercem maior efeito na distribuição espacial da chuva no MS. As equações de regressão linear múltipla geradas neste estudo subsidiarão trabalhos de zoneamento de culturas, indicação de épocas de semeadura, irrigação, determinação de potencial de rendimento, zoneamento de riscos climáticos, crédito e seguro agrícola.

PALAVRAS-CHAVE: Correlação. Regressão linear múltipla. Análise de trilha.

\section{REFERENCES}

ANA - Agência Nacional de Águas. Available at: http://hidroweb.ana.gov.br. Access in: 29 out. 2014.

ANDRÉ, R. G. B.; MARQUES, V. S.; PINHEIRO, F. M. A.; FERRAUDO, A. S. Identificação de regiões pluviometricamente homogêneas no estado do Rio de Janeiro, utilizando-se valores mensais. Revista Brasileira de Meteorologia, Rio de Janeiro, v. 23, n. 4, p. 501-509, 2008.

ÁVILA, L. F.; MELLO, C. R.; VIOLA, M. R. Mapeamento da precipitação mínima provável para o sul de Minas Gerais. Revista Brasileira de Engenharia Agrícola e Ambiental, Campina Grande, v. 13 (Suplemento), p. 906-915, 2009. http://dx.doi.org/10.1590/s1415-43662009000700013

BAÚ, A. L.; GOMES, B. M.; QUEIROZ, M. M. F., OPAZO, M. A. U.; SAMPAIO, S. C. Comportamento espacial da precipitação pluvial mensal provável da mesoregião oeste do Estado do Paraná. Irriga, Botucatu, v. 11, n. 2, p. 150-168, 2006. 
CAMARGO, A. P.; GHIZZI, S. M. Estimativa das temperaturas médias com base em cartas de temperatura potencial normal ao nível do mar para a região sudeste do Brasil. Campinas, n.141, 1991. 17p. Boletim Técnico IAC.

CARGNELUTTI FILHO, A.; MALUF, J. R. T.; MATZENAUER, R; STOLZ, A. P. Altitude e coordenadas geográficas na estimativa da temperatura mínima média decendial do ar no estado do Rio Grande do Sul. Pesquisa Agropecuária Brasileira, Brasília, v. 41, p. 893-901, 2006. http://dx.doi.org/10.1590/S0100-204X2006000600001

CARNELUTTI FILHO, A.; MALUF, J. R. T.; MATZENAUER, R. Coordenadas geográficas na estimativa das temperaturas máxima e média decendiais do ar no Estado do Rio Grande do Sul. Ciência Rural, Santa Maria, v. 38, n. 9, p. 2448-2456, dez, 2008. http://dx.doi.org/10.1590/S0103-84782008000900006

CAVALCANTI, E. P.; SILVA, E. D. V. Estimativa da temperatura do ar em função das coordenadas locais. In: Congresso Brasileiro de Meteorologia, 7, Congresso Latino-Americano e Ibérico de Meteorologia, 1994, Belo Horizonte. Anais..., Belo Horizonte: Sociedade Brasileira de Meteorologia, 1994, p. 154-157.

COELHO, D. T.; SEDIYAMA, G. C.; VIEIRA, M. Estimativa das temperaturas médias mensais e anual no Estado de Minas Gerais. Revista Ceres, Viçosa, v. 20, p. 455-459, 1973.

CONAB: Companhia Nacional de Abastecimento. Acompanhamento de safra brasileira: grãos, décimo levantamento, julho 2014.

CORREA, C. C. G.; TEODORO, P. E.; CUNHA, E. R.; OLIVEIRA-JÚNIOR, J. F.; GOIS G.; RIBEIRO, L.P.; BACANI, V. M.; TORRES, F. E. Spatial interpolation of annual rainfall in the State Mato Grosso do Sul (Brazil) using different transitive theoretical mathematical models. International Journal of Innovative Research in Science, Engineering and Technology, Tamilnadu, v. 3, n. 10, p. 16618-16625, 2014. http://dx.doi.org/10.15680/IJIRSET.2014.0310006

CRUZ, C. D. GENES - a software package for analysis in experimental statistics and quantitative genetics. Acta Scientiarum Agronomy, Maringá, v.35, p.271-276, 2013.

FEITOZA, L. R.; SCÁRDUA, J. A.; SEDIYAMA, G. C.; VALLE, S. S. Estimativas das temperaturas médias das máximas mensais e anual do Estado do Espírito Santo. Ciência Rural, Santa Maria, v. 10, p. 25-32, 1980 b.

FEITOZA, L. R.; SCÁRDUA, J. A.; SEDIYAMA, G. C.; VALLE, S. S. Estimativas das temperaturas médias das mínimas mensais e anual do Estado do Espírito Santo. Ciência Rural, Santa Maria, v. 10, p. 15-24, 1980a.

FERREIRA, M.; BURIOL, G. A.; ESTEFANEL, V.; PINTO, H. S. Estimativa das temperaturas médias mensais e anuais do Estado do Rio Grande do Sul. Ciência Rural, Santa Maria, v. 1, p. 21-52, 1971.

FERREIRA, M.; BURIOL, G. A.; PIGNATARO, I. A. B.; ESTEFANEL, V. Estimativa das temperaturas médias mensais e anuais do Estado de Santa Catarina. Ciência Rural, Santa Maria, v. 4, p. 19-38, 1974.

HOFFMANN, R.; VIEIRA, S. Análise de regressão: uma introdução à econometria. 3.ed. São Paulo: Hucitec/Edusp, 1998. 379p.

LYRA, G. B.; OLIVEIRA-JÚNIOR, J. F.; ZERI, M. Cluster analysis applied to the spatial and temporal variability of monthly rainfall in Alagoas state, Northeast of Brazil. International Journal of Climatology, Chichester, v. 34, p. 35463558, 2014. http://dx.doi.org/10.1002/joc.3926

LIMA, M. G.; RIBEIRO, V. Q. Equações de estimativa da temperatura do ar para o Estado do Piauí. Revista Brasileira de Agrometeorologia, Rio de Janeiro, v. 6, p. 221-227, 1998. 
LUIZ, A. J. B.; SILVA, F. A. M. Temperaturas decendiais máxima, mínima e média, como função da latitude e altitude, em Goiás. In: Congresso Brasileiro de Agrometeorologia, 9, 1995, Campina Grande. Anais... Campina Grande: SBA, 1995. p. 234-235.

MARIN, F. R.; PANDORFI, H.; FERREIRA, A. S. Estimativa das temperaturas máximas, mínimas e médias mensais para o Brasil. In: Congresso Brasileiro de Agrometeorologia, 13., 2003, Santa Maria. Anais..., Santa Maria: SBA 2003. CD-ROM.

MEDEIROS, S. S.; CECÍLIO, R. A.; MELO JÚNIOR, J. C. F.; SILVA JÚNIOR, J. L. C. Estimativa e espacialização das temperaturas do ar mínimas, médias e máximas na Região Nordeste do Brasil. Revista Brasileira de Engenharia Agrícola e Ambiental, Campina Grande, v. 9, n. 2, p. 247-255, 2005. http://dx.doi.org/10.1590/S1415-

43662005000200016

PEDRO JÚNIOR, M. J.; MELLO, M. H. D. A.; ORTOLANI, A. A.; ALFONSI, R. R.; SENTELHAS, P. C. Estimativa das temperaturas médias mensais das máximas e das mínimas para o Estado de São Paulo. Campinas: Instituto Agronômico, 1991. 11p. (Boletim técnico, 142).

SEDIYAMA, G. C.; MELO JÚNIOR, J. C. F. Modelos para estimativa das temperaturas normais mensais médias, máximas, mínimas e anual no Estado de Minas Gerais. Engenharia na Agricultura, Viçosa, v. 6, p. 57-61, 1998.

SEDIYAMA, G. C.; MELO JÚNIOR, J. C. F.; SANTOS, A. R.; SOUZA, J. A.; SANTANA, M. O. Modelo para estimativa das temperaturas normais mensais médias, máximas, mínimas e anual georreferenciados para o Estado do Espírito Santo. In: Congresso Brasileiro Engenharia Agrícola, 31, 2002, Salvador. Anais..., Salvador: Sociedade Brasileira de Engenharia Agrícola, 2002. CD-ROM.

SOUZA, G. S. Introdução aos modelos de regressão linear e não-linear. Brasília: Embrapa-SPI/Embrapa-SEA, 1998. $505 \mathrm{p}$.

TEODORO, P. E.; CORREA, C. C. G.; TORRES, F. E.; OLIVEIRA-JÚNIOR, J. F.; SILVA JUNIOR, A. C.; GOIS, G.; DELGADO, R. C. Analysis of the Occurrence of Wet and Drought Periods Using Standardized Precipitation Index in Mato Grosso do Sul State, Brazil. Journal of Agronomy (Print), Nova York, v. 14, p. 80-86, 2015a. http://dx.doi.org/10.3923/ja.2015.80.86

TEODORO, P. E.; OLIVEIRA-JUNIOR, J. F.; CUNHA, E. R.; CORREA, C. C. G.; TORRES, F. E.; BACANI, V. M.; GOIS, G.; RIBEIRO, L. P. Cluster analysis applied to the spatial and temporal variability of monthly rainfall in Mato Grosso do Sul State, Brazil. Meteorology and Atmospheric Physics (Print), Viena, v. 126, p. 1-13, 2015 b. http://dx.doi.org/10.1007/s00703-015-0408-y

TEODORO, P. E.; SILVA JUNIOR, A. C.; CORREA, C. C. G.; RIBEIRO, L. P.; OLIVEIRA, E. P.; LIMA, M. F.; TORRES, F. E. Path analysis and correlation of two genetic classes of maize (Zea mays L.). Journal of Agronomy, New York, v. 13, p. 23-28, 2014. http://dx.doi.org/10.3923/ja.2014.23.28

TORRES, F. E.; CARGNELUTTI FILHO, A.; TEODORO, P. E.; CORREA, C. C. G.; RIBEIRO, L. P.; CUNHA, E. R. Dimensionamento amostral para a estimação da média de precipitação pluvial mensal em locais do Estado do Mato Grosso do Sul. Ciência Rural, Santa Maria, v. 46, p. 60-69, 2016. http://dx.doi.org/10.1590/0103-8478cr20150348

VENCOVSKY, R.; BARRIGA, P. Genética biométrica no fitomelhoramento. Ribeirão Preto: Sociedade Brasileira de Genética, 1992. 496p.

ZAVATTINI, J. A. As chuvas e as massas de ar no estado de Mato Grosso do Sul: estudo geográfico com vista à regionalização climática. São Paulo: Editora UNESP, 2009, 212 p. 